\title{
Penerapan Service Engineering Framework Pada Arsitektur SISTEM BERORIENTASI SERVICE
}

\author{
APPLICATION FRAMEWORK IN ENGINEERING SERVICE ORIENTED ARCHITECTURE \\ SYSTEM SERVICE
}

\author{
${ }^{1}$ Ade Hodijah \\ ${ }^{1}$ Jurusan Teknik Komputer dan Informatika,Politeknik Negeri Bandung, Jl. Geger Kalong Hilir, Desa \\ Ciwaruga, Parongpong, Kabupaten Bandung Barat, Jawa Barat 40012 \\ e-mail: ${ }^{1}$ adehodijah@jtk.polban.ac.id
}

\begin{abstract}
The Service Engineering (SE) is understood as a framework to create innovative services in application development of information technology approach to Service Oriented Architecture (SOA). Implementing SOA is required methodology to identify services that can be used again in the application and organization of a company. in this research, software development model used is object-oriented methodologies, SOA itself is a collection consisting of tools, technologies, frameworks, and best practices that facilitate the implementation of a service quickly. in a study this uses the tools of Business Process Management System (BPMS) to support the implementation of service-oriented software. the purpose of this study is to produce a model of activities and artifacts of the application software development models of the SE with a case study Rate Loans. Validation to the design of the model is done through testing of the software produced. The results showed that the application of the SE in the development of service-oriented software can use the object-oriented methodology by providing additional value-added analysis and redesign of business processes to be implemented on a BPMS. BPMS usage of the application of the SE on the SOA has the advantage of visualization in the management of business processes.
\end{abstract}

Keywords: SE, SOA, BPMS

\begin{abstract}
Abstrak. Service Engineering (SE) dipahami sebagai framework untuk menciptakan inovasi service dalam pengembangan aplikasi Teknologi Informasi melalui pendekatan Service Oriented Architecture (SOA). Dalam mengimplementasi SOA diperlukan metodologi untuk mengidentifikasi service yang dapat dipergunakan kembali dalam aplikasi dan organisasi suatu perusahaan. Pada penelitian ini model pengembangan perangkat lunak yang digunakan adalah metodologi berorientasi objek. SOA sendiri merupakan sebuah kumpulan yang terdiri atas tools, teknologi, framework, dan best practice yang memudahkan implementasi sebuah service secara cepat. Dalam penelitian ini, digunakan alat bantu Business Process Management System (BPMS) untuk menunjang implementasi perangkat lunak berorientasi service. Tujuan penelitian ini adalah menghasilkan model aktifitas dan artifak dari penerapan model pengembangan perangkat lunak dari SE dengan studi kasus Penilaian Pinjaman. Validasi terhadap rancangan model dilakukan melalui pengujian terhadap perangkat lunak yang dihasilkan. Hasil penelitian menunjukkan bahwa penerapan SE dalam pengembangan perangkat lunak berorientasi service dapat menggunakan metodologi berorientasi objek dengan melakukan penambahan analisis value added dan perancangan ulang proses bisnis untuk dapat diimplementasikan pada BPMS. Penggunaan BPMS dari penerapan SE pada SOA memiliki keunggulan dalam visualisasi dalam pengelolaan proses bisnis.
\end{abstract}

Kata kunci: SE, SOA, BPMS 


\section{Pendahuluan}

SOA adalah sebuah kumpulan yang terdiri atas tools, teknologi, framework, dan best practice yang memudahkan implementasi sebuah service secara cepat [1]. Service adalah sebuah fungsi atau sekumpulan fungsi atau aktifitas yang menggambarkan tugas tertentu dan dapat dipanggil atau digunakan jika diperlukan [2].

Pada penelitian [3], metodologi pengembangan aplikasi SOA yang digunakan adalah Service Oriented Modeling and Architecture (SOMA) dan analisis inovasi service menggunakan Business Model Canvas (BMC). Dimana SOMA sangat direkomendasikan karena komprehensif, dapat diadopsi oleh industri besar, dan mencakup siklus SE yang lengkap dari sisi bisnis sampai implementasi teknisnya; sementara BMC merupakan pemodelan bisnis yang menjelaskan dasar dari bagaimana organisasi menciptakan, menyampaikan, dan menangkap nilai (value added). Namun untuk menganalisis kebutuhan pada studi kasus Pengajuan Pinjaman ini, mengidentifikasi service dan memodelkan proses bisnis digunakan pendekatan True Requirement Investigation pada tahap Identify [3] melalui penerapan konsep Business Process Modeling (BPM) [4]. Kemudian pada tahap Design [3] diawali sub-proses service process design, yakni analisis proses bisnis (to-be) sesuai konsep redesign dari BPM [4]. Untuk melakukan implementasi aplikasi berbasis SOA pada tahap Prototyping [3] digunakan alat bantu BPMS guna mendukung penciptaan inovasi service. Dimana inovasi service sendiri muncul karena adanya pergeseran perspektif dari product-based menjadi service-based dengan Teknologi Informasi memiliki peran yang signifikan dalam mewujudkannya [6]. Inovasi service memiliki dampak potensial untuk meningkatkan produktifitas dan kualitas service [7]. Penciptaan inovasi service pada penelitian ini adalah kemudahan dalam pengubahan proses bisnis dengan meminimalisir pengerjaan pengubahan kode program melalui alat bantu BPMS. Proses diawali dengan mengetahui value bisnis dari setiap kegiatan operasional untuk menentukan komponen mana yang menjadi prioritas. Dalam penelitian ini, untuk menentukan komponen-komponen mana yang tepat dalam pengembangan perangkat lunak, diperlukan suatu analisis terlebih dahulu, salah satu cara menggunakan Porter's Value Chain [8]. Dalam melakukan analisis value chain sekumpulan rantai aktivitas diidentifikasi untuk menghasilkan service dari awal proses masuknya input, kemudian proses operasional sampai dihasilkan output, dan setiap mata rantai aktivitas terdapat penambahan nilai (value added) dimana perangkat lunak dapat memberikan dampak yang strategis.

Berdasarkan pendahuluan di atas, maka masalah-masalah penelitian yang dikaji adalah sebagai berikut: (1) Aktifitas apakah yang diperlukan dalam melakukan analisis kebutuhan perangkat lunak, identifikasi service, dan memodelkan proses bisnis menggunakan pendekatan True Requirement Investigation dari SE melalui penerapan BPM pada SOA? (2) Apa sajakah artifak yang dihasilkan dalam melakukan pengembangan perangkat lunak berorientasi service dengan menggunakan metodologi pengembangan perangkat lunak berorientasi objek dari RUP [5] dengan proses analisis dan desain menggunakan pendekatan dari Elements of Service-Oriented Analysis and Design (SOAD) [14] melalui alat bantu BPMS?. Aktifitas dan artifak yang akan dikaji dalam penelitian ini dilakukan pada studi kasus Penilaian Pinjaman [13], yakni fokus pada proses Pengajuan Pinjaman saja.

Adapun tujuan yang ingin dicapai dalam penelitian ini adalah sebagai berikut: (1) Menganalisis aktifitas yang diperlukan untuk mengetahui kebutuhan perangkat lunak, mengidentifikasi service, memodelkan proses bisnis melalui penerapan BPM 
pada SOA; (2) Merancang artifak yang diperlukan dalam melakukan pengembangan perangkat lunak berorientasi service dengan menggunakan metodologi pengembangan perangkat lunak berorientasi objek dari RUP; (3) Mengimplementasikan hasil rancangan artifak yang diperlukan dalam pengembangan perangkat lunak berorientasi service menggunakan BPMS. Dengan urgensi penelitian sebagai berikut: (1) Penelitian ini dianggap penting karena hasilnya dapat memberikan pendekatan praktis, dalam hal ini bagaimana penerapan framework SE khususnya aktifitas dan artifak yang dihasilkan dari pengembangan perangkat lunak berorientasi service melalui penggunaan alat bantu BPMS; (2) Bagi peneliti, dari hasil penerapan terhadap langkah-langkah bagaimana mengembangkan aplikasi berbasis SOA dengan alat bantu BPMS, sehingga dapat menyusun dan mengembangkan bahan ajar dan buku ajar sebagai acuan bagi pengajar. Berikut langkah-langkah yang akan diadaptasi sebagai metode penelitian dalam penerapan framework SE pada aplikasi berorientasi service.

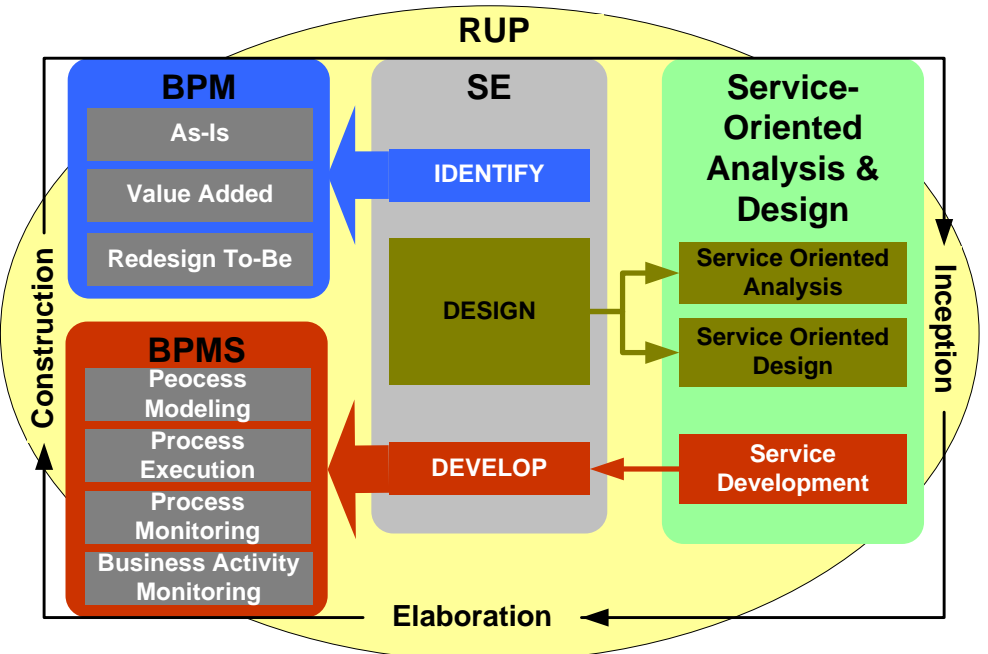

Gambar 1. Gabungan fase SE, BPM, BPMS, SOAD dengan RUP [12]

\section{Metodologi Penelitiam}

Pada tahap ini dilakukan identifikasi permasalahan dan solusi terkait proses bisnis Pengajuan Pinjaman. Komponen bisnis dari Pengajuan Pinjaman terdiri dari tiga proses, yaitu: Pembuatan Pinjaman, Persetujuan Pengajuan, dan Penyajian Laporan Pengajuan. Berikut gambaran dari proses bisnis Pengajuan Pinjaman.

\begin{tabular}{|c|c|c|}
\hline \multicolumn{3}{|c|}{ Manajemen Keuangan } \\
\hline \multicolumn{3}{|c|}{ Manajemen Pinjaman } \\
\begin{tabular}{c|c} 
Pembuatan \\
Pinjaman
\end{tabular} & $\begin{array}{c}\text { Persetujuan } \\
\text { Pengajuan }\end{array}$ & $\begin{array}{c}\text { Penyajian Laporan } \\
\text { Pengajuan }\end{array}$ \\
\hline
\end{tabular}

Gambar 1. Value chain untuk proses Pengajuan Pinjaman

Selanjutnya dilakukan analisis komponen bisnis mana yang menjadi prioritas [8]. Komponen bisnis yang berwarna kuning pada gambar di atas merupakan hot component yang dijadikan prioritas untuk perbaikan, yakni proses Persetujuan Pengajuan. Dimana data pengajuan pinjaman berasal dari beragam beragam kantor cabang dengan hirarki 
persetujuan pinjaman dan memerlukan data informasi pinjaman yang diperoleh secara manual dari aplikasi legacy yang terpisah, sementara proses Pembuatan Pinjaman dilakukan di satu kantor cabang tertentu dengan sumber data yang sudah dimilikinya.

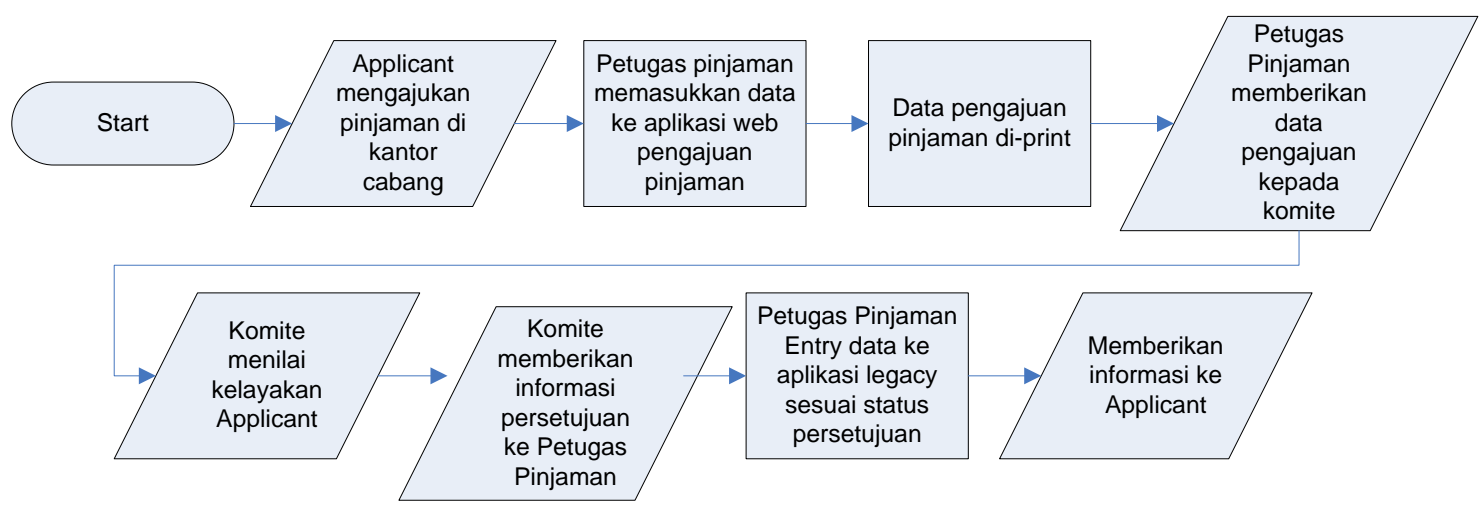

Gambar 2. Proses bisnis as-is untuk Persetujuan Pengajuan

Berdasarkan True Requirement Investigation dari [6], dilakukan analisis komponen prioritas dari [8] dan analisis prose bisnis dari [9] dengan aktifitas dasar analisis requirement dari [10], dihasilkan identifikasi permasalahan dan solusi terkait proses bisnis Persetujuan Pengajuan sebagai berikut:

- List of problems, masalah-masalah yang ada dengan mengacu pada [13] yaitu:

- Variasi proses dari setiap hirarki pada Persetujuan Pengajuan, terkait informasi yang diperlukan dan pemberian status persetujuan.

- Perolehan informasi pinjaman dari aplikasi legacy dilakukan secara manual, yakni diperlukan bantuan dari Petugas Informasi Pinjaman.

- List of directives, acuan untuk menyelesaikan masalah-masalah tersebut berdasarkan pertimbangan competitive advantage, bahwa terdapat tiga hal utama yang harus dievaluasi untuk membuat sebuah perusahaan/organisasi memiliki nilai lebih dibanding perusahaan/organisasi lain yaitu: bisnis perusahaan/organisasi, produk atau jasa yang dihasilkan, dan proses bisnis dalam menjalankan perusahaan/organisasi [9]. Dimana SOA memungkinkan terjadinya integrasi diantara proses bisnis dan infrastruktur teknologi informasi, yakni tahap analisis dan perancangan sebuah service diturunkan dari proses bisnis perusahaan/organisasi. Dimana kategori service pada penelitian ini adalah business service, sebagai aktivitas bisnis yang disediakan oleh service provider untuk service consumer dalam rangka menciptakan value kepada pelanggan [16].

- List of opportunity, solusi berdasarkan acuan dalam penyelesaian masalah-masalah tersebut melalui pemanfaatan BPM untuk mengevaluasi dan memperbaiki proses bisnis [9].

\section{Analisis dan Pembahasan}

\section{Tahap Design}

Berdasarkan permasalahan yang dihadapi, maka inovasi service yang diusulkan dari studi kasus pada penelitian ini yaitu merancang pengelolaan proses bisnis Persetujuan Pengajuan yang akan memberikan otomatisasi pada perolehan informasi pinjaman dan status pengajuan yang dihasilkan untuk setiap iterasi dari hirarki persetujuan dengan asumsi bahwa service innovation memiliki dampak potensial untuk 
meningkatkan produktifitas. Berikut hasil redesign proses bisnis to-be dari Persetujuan Pengajuan.

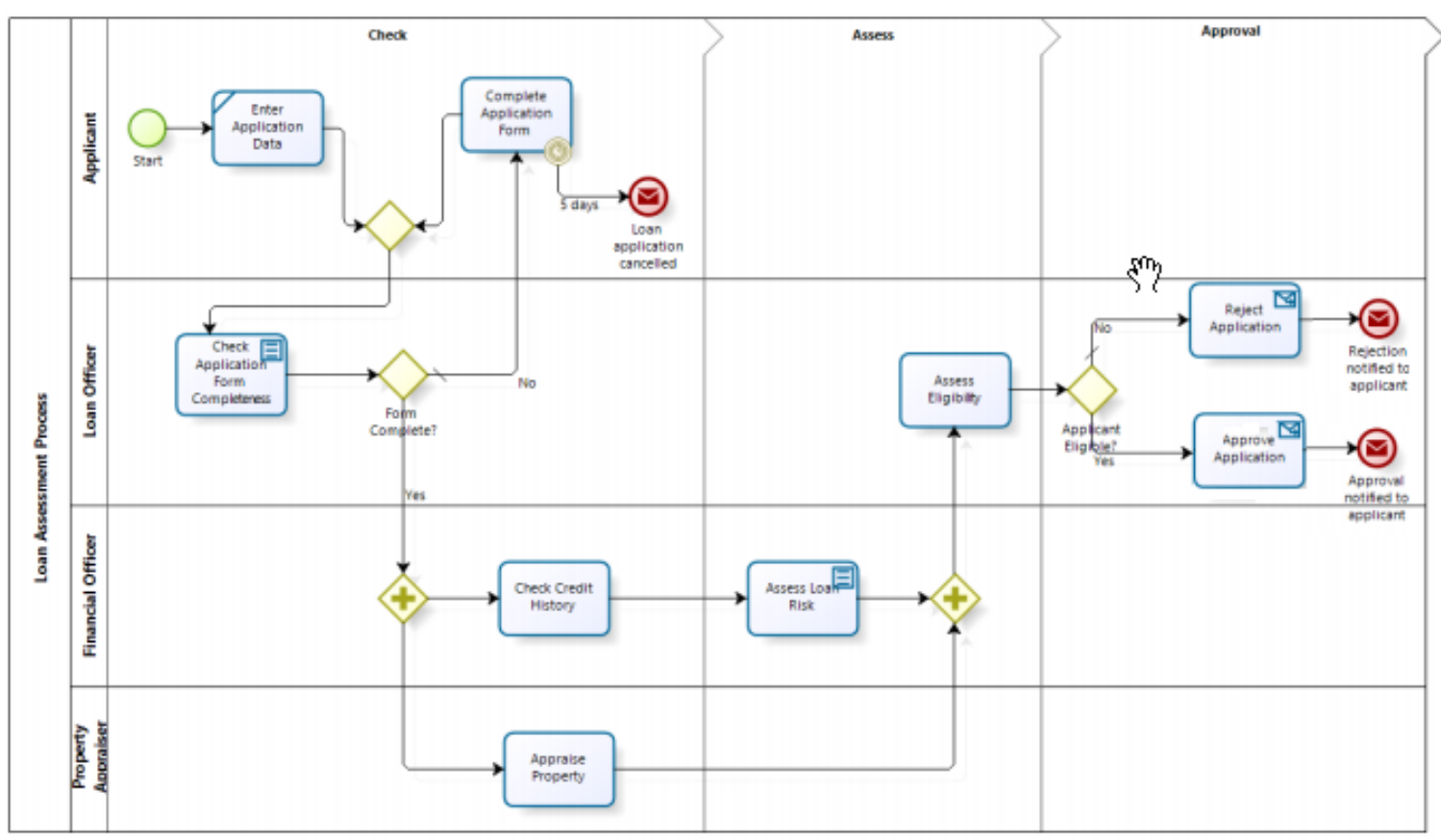

Gambar 3. Proses bisnis to-be untuk Persetujuan Pengajuan

Beberapa metode untuk memodelkan service diantaranya melalui analisis task-centric dan entity-centric [2]. Pada penelitian ini digunakan entity-centric, dikarenakan pendekatan ini akan menghasilkan perangkat lunak yang lebih moduler [4]. Oleh karena itu, dilakukan analisis terhadap entitas dari aplikasi Persetujuan Pengajuan, yakni entitas Proposal, Approval, dan User. Tiga entitas tersebut merupakan kandidat service. Berikut operasi service untuk setiap entitas dari studi kasus Persetujuan Pengajuan.
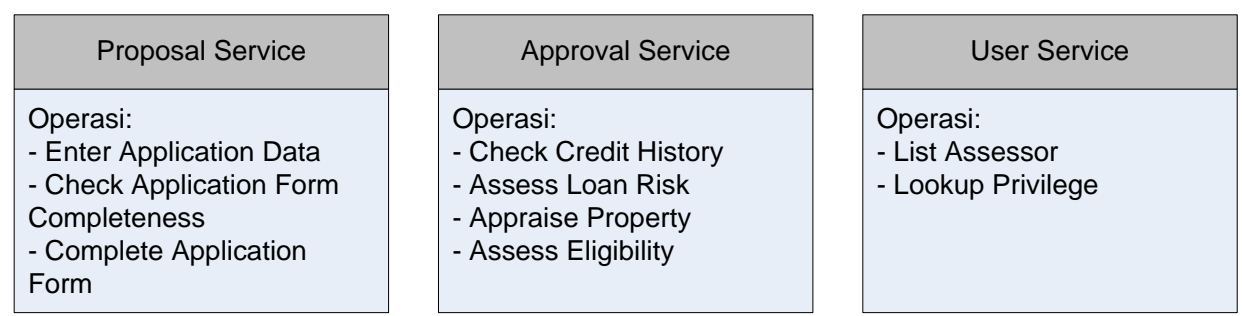

Gambar 4. Model service untuk Persetujuan Pengajuan

Model stuktur data diturunkan dari proses tertentu pada proses bisnis sesuai kebutuhan data untuk menjalankan operasi service. Berikut rancangan struktur data pada aplikasi dari studi kasus Persetujuan Pengajuan. 


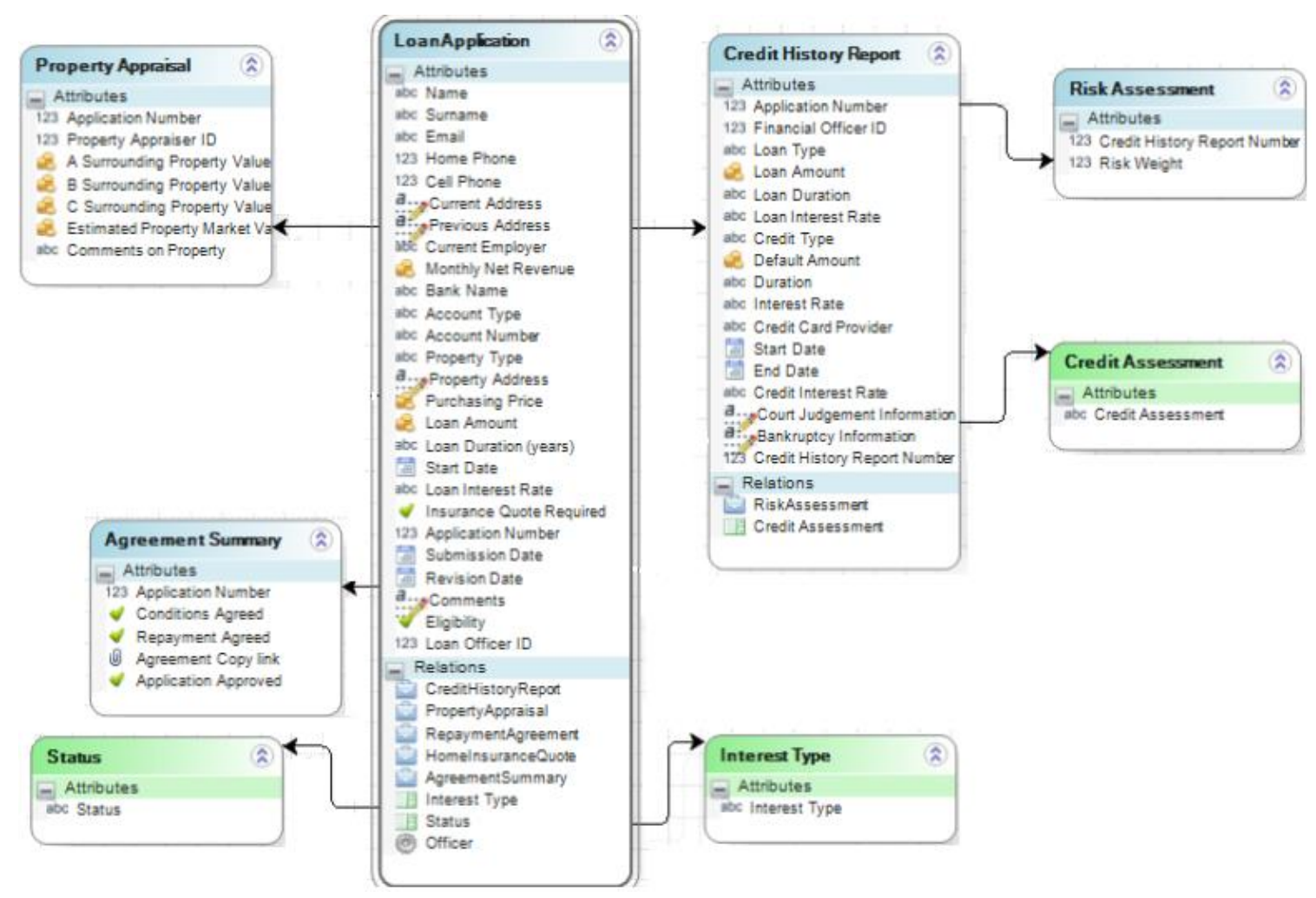

Gambar 5. Model data untuk Persetujuan Pengajuan

\section{Tahap Develop}

Bizagi Studio sebagai tekonologi untuk menunjang pengerjaan BPM pada perangkat lunak memiliki lima tahapan untuk mengembangkan aplikasi berorientasi service [15]. Setiap tahapan tersebut akan disimpan hasilnya dalam database SQL server. Dimana tahapan-tahapan tersebut sebagai komponen umum yang dimiliki oleh alat bantu BPMS [11]. Berikut tahapan untuk mengembangkan aplikasi berorientasi service dari studi kasus pada penelitian ini [14]:

1. Memodelkan proses dari proses bisnis to-be (Model the process)

2. Memodelkan struktur data dari proses (Process data)

3. Merancang form atau user interface (UI) untuk setiap operasi service (Forms Creation)

4. Mendefinisikan aturan bisnis dari setiap operasi service (Business rules)

5. Menentukan pengguna service (Performers)

Pembuatan rancangan aplikasi pada tahap 1 - 3 sudah dilakukan pada tahap Design, selanjutnya dilakukan Business rules dan performers.

Business rules bertujuan untuk mengendalikan alur dari proses Persetujuan Pengajuan sesuai rancangan dari proses bisnis to-be. Berikut tahapan pendefinisian untuk Business rules.

1. Transition Conditions, terdiri dari: Incomplete, Complete, Canceled, Approved, Rejected.

2. Activity Actions, tediri dari: Check Application Form Completeness, Assess Loan Risk, Assess Eligibility, Reject Application, Approve Application.

3. Event Actions, terdiri dari: Loan application canceled, Rejection notified to applicant, Rejection notified to applicant. 


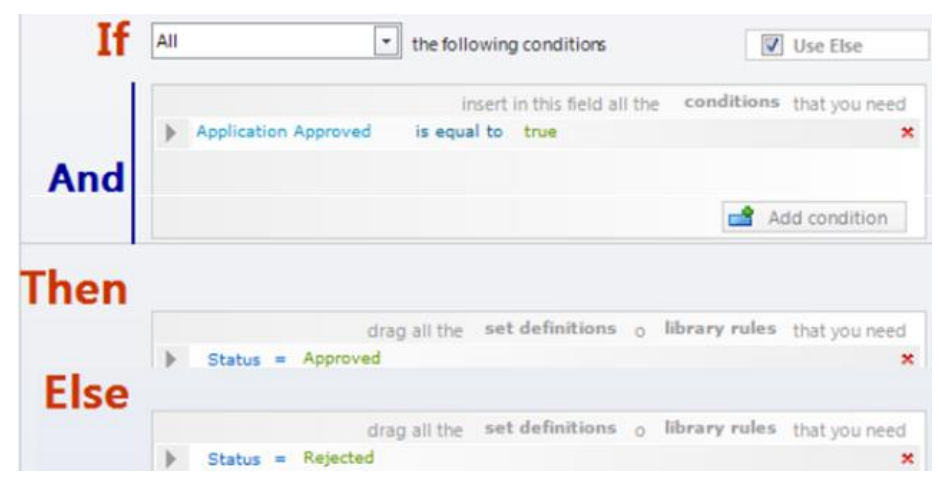

Gambar 6. Business rules untuk Persetujuan Pengajuan

Terdapat empat kategori pengguna (performers) dari aplikasi Persetujuan Pengajuan, yaitu: Applicant, Financial Officer, Property Appraiser, serta Loan Officer. Berikut salah satu tampilan penentuan performers untuk pengguna sebagai Loan Officer.

\begin{tabular}{l} 
User Property: \\
\hline Positions $\quad-7$ Equals $\quad \nabla$ Entity Value : \\
\hline
\end{tabular}

Gambar 7. Performers untuk Persetujuan Pengajuan

\section{Pengujian Perangkat Lunak}

Pengujian perangkat lunak bertujuan untuk memastikan bahwa rancangan dimulai dari model proses, model data, model UI, pendefinisian aturan bisnis beserta pengguna dari setiap operasi service dapat berjalan dengan baik sesuai requirement dari proses Persetujuan Pengajuan. Berikut tampilan hasil persetujuan atas pengajuan sebuah pinjaman dengan pengguna sebagai Loan Officer.

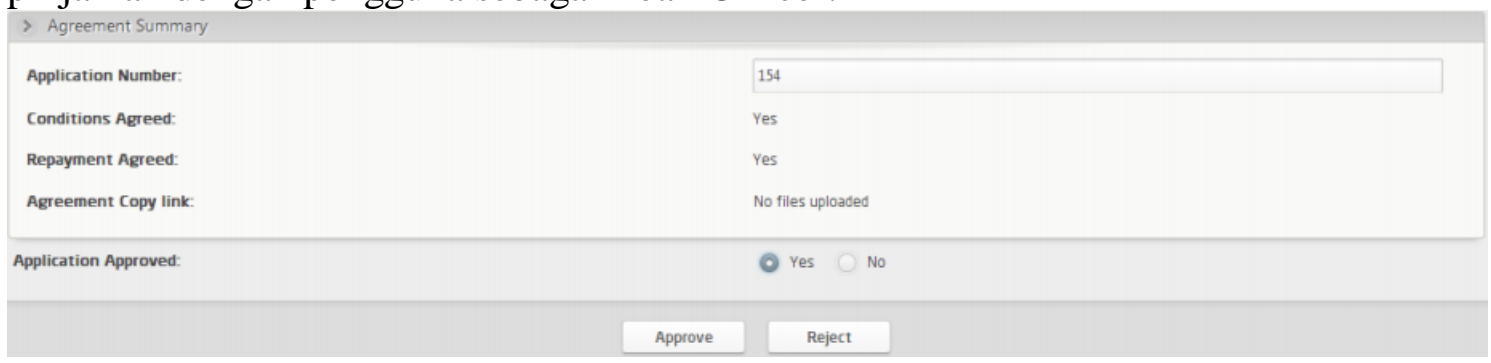

Gambar 8. Informasi hasil persetujuan atas Pengajuan Pinjaman

Ketika terjadi perubahan proses bisnis dari Persetujuan Pengajuan, misal terjadi perubahan (penambahan atau pengurangan) urutan dari hararki persetujuan, maka bisa dilakukan pada pengubahan Model the process. Namun jika terjadi penambahan urutan dari hirarki persetujuan maka dibutuhkan pendefinisian ulang aturan aktfitas beserta resources yang dibutuhkan dari setiap aktifitas tersebut, yakni lakukan Business rules dan Performers dari langkah pembuatan perangkat lunak dengan menggunakan Bizagi Studio.

\section{Kesimpulan}

Berikut kesimpulan dari penelitian sebagai berikut:

- Analisis dan perancangan arsitektur SOA dari perangkat lunak berorientasi service berhasil diterapkan pada framework SE, yakni pada tahap Design untuk digunakan sebagai dasar pembuatan prototipe service pada tahap Develop dengan dukungan konsep BPM yang dimulai pada tahap Identify. 
- Terdapat 3 bagian yang dihasilkan dari pengembangan perangkat lunak menggunakan BPMS, yaitu aplikasi-aplikasi client, proses bisnis, dan sekumpulan web service. Pembagian ini memberikan nilai lebih dengan meminimalkan ketergantungan antara proses bisnis (logic), fungsi bisnis (service), dan aplikasi yang berinteraksi dengan pengguna (client).

Rekomendasi terkait penggunaan BPMS untuk mengembangkan aplikasi berbasis SOA adalah kajian dan eksplorasi lebih lanjut terkait fungsi-fungsi dasar BPEL dan pengunaan BPMN yang belum diimplementasikan secara sempurna pada penelitian ini.

\section{Ucapan Terima Kasih}

\section{Daftar pustaka}

[1] Kunal Mittal. 2007. Service Oriented Unified Process (SOUP). [Online]. http://www.kunalmittal.com/html/soup.html. [Dikunjungi Agustus 2016].

[2] Erl, Thomas. 2005. Service-Oriented Architecture: Concepts, Technology, and Design. Prentice Hall PTR. [Online]. http://hexawebhosting.com/getfile-326.zip. [Dikunjungi Mei 2016].

[3] Suhardi, Robin Doss, and Purnomo Yustianto. 2015. Service Engineering Based on Service Oriented Architecture Methodology. TELKOMNIKA Telecommunication, Computing, Electronics and Control, vol. 13, no. 4.

[4] Panggabean, G.F. 2010. Studi Framework Pembangunan Aplikasi Berbasis SOA dan BPM. Tesis. STEI-ITB.

[5] Larman, Craig. 2004. Applying UML And Patterns: An Introduction to Object-Oriented Analysis and Design and the Unified Process. Edisi 3.

[6] Suhardi, Pathya Budhiputra, Purnomo Yustianto. 2014. Service Engineering Framework: A Simple Approach. International Conference of Information Technology System and Innovation (ICITSI).

[7] J Sphorer, P Maglio. 2008. The Emergence of Service Science: Toward systematic service innovation to accelerate co-creation value. IBM Almaden Research Center.

[8] Turban, Leidner, McLean, Wetherbe. 2008. Information Technology for Management. [Online]. http://www.google.co.id/url?sa=t\&source=web\&cd=3\&ved=0CC8QFjAC\&url=http\%3A\%2F\%2Fsp uccourseware.east.spu.ac.th\%2Fdocument $\% 2$ Ftautong\%2FInformation $\% 2520$ Technology\%2520for \%2520Management $\% 2520 \% 286 \mathrm{th} \% 2520$ Edition\%29.ppt\&rct=j\&q=ppt\%20information\%20technol ogy\%20for\%20management\%2C\%20turban\&ei=WimRTtOEAY. [Dikunjungi Mei 2016].

[9] Harmon, Paul. 2007. Business Process Change, A Guide for Business Mangers and BPM and Six Sigma Professional. 2nd Edition. Burlington, USA. Morgan Kaufmann Publishers is an imprint of [Online]. http://www.filesonic.com/file/23091133/Business_Process_Management,_Second_Edition__Practical_Guidelines_to_Successful_Implementations.rar [Dikunjungi Mei 2016].

[10] Jeffrey Whitten and Lonnie Bentley. 2007. System Analysis and Design Methods. New York, USA: McGraw-Hill, Inc.

[11] Newcomer, Eric dan Greg Lomow. 2004. Understanding SOA With Web Services. Addison Wesley Professional.

[12] Hodijah, Ade. 2016. Perancangan Model Pengembangan Perangkat Lunak Berbasis Service Oriented Architecture Menggunakan Pendekatan Service Engineering Framework. Prosiding SNaPP Sains dan Teknologi, UNISBA.

[13] Loan Assessment Process Lab. 2013. [Online] http://fundamentals-of-bpm.org/wpcontent/uploads/LoanAssessmentProcessDescription.zip. [Dikunjungi September 2016]

[14] Zimmermann, Olaf, dkk. 2004. Elements of Service-Oriented Analysis and Design. [Online]. http://www.ibm.com/developerworks/library/ws-soad1/. [Dikunjungi Juli 2016].

[15] Bizagi $\quad$ Web $\quad$ Services $\quad$ (SOA $\quad$ Layer). $\quad$ Online]. http://help.bizagi.com/bpmsuite/en/index.html?soa_layer.htm. [Dikunjungi Juni 2016]

[16] J Cardoso, K Voigt, and M Winkler. 2009. Service engineering for the internet of services. Enterprise Information System, pp. 15-27. 